\title{
Effect of Sprouting on invitro digestibility of some locally consumed leguminous seeds. \\ ${ }^{1}$ *AKPORHONOR, E E; ${ }^{2}$ EGWAIKHIDE, P A; ${ }^{2}$ EGUAVOEN, I.O
}

\author{
${ }^{1}$ Department of Chemistry, Delta State University, Abraka. \\ ${ }^{2}$ Department of Chemistry, Ambrose Alli University, Ekpoma
}

\begin{abstract}
Local cultivars of some commonly consumed legume seeds: cowpea (Vigna unguiculata), soya beans (Glycine max) and Bambara beans (vigna subterranena) were sprouted for three days. Dried pulverized samples of raw or cooked form of the respective (cooking time I hr. 30mins.) samples of sprouted and unsprouted were assessed for the in vitro protein digestibility. Sprouting and cooking failed to improve invitre digestibility of Soya beans $(95.81 \pm 0.37)$ and Bambara beans $(92.79 \pm 0.40)$. Generally, improved digestibility was recorded to indicate decreased level of non digentible oligosaccharide content of the legumes. @JASEM
\end{abstract}

It is well documented that the developing countries do not produce enough food and of the right nutritional quality to met daily needs.(Aletor, and Aladeetimi, (1989). The dearth in food supply especially of protein is of such magnitude that he developing nations have to depend mostly on cereals, grains, starch roots and tubers for energy and protein need (Auret. and Behar Syndrome, (1953). The net of effect of this protein deficit in the developing countries is manifested in the prevalence of various forms of protein calorie malnutrition (ICM) diseases such as Kwashiokor, marasmus and mental deficiencies (Bressani,. (1975). Legumes contain variable levels of carbohydrate. The Oligosaccharide content of starchyose, raddinose and veerbascose are not digested by human beings but are fermented in the colon and produce gases such as hydrogen $\left(\mathrm{H}_{2}\right)$, carbon (IV) oxide and traces of methane $\left(\mathrm{CH}_{4}\right)$. This produces a condition called flatulence which may induce increased belching and heart-burn in some people. Other constraints to the increased use of legumes include the presence of anti-nutrient such as trypsin inhibitor, tannins hemaglutanins, phytates, anthocyanniona, unacceptabl taste/flavor and the long and tedious cooking/processing time (Bedsheh, Sattar. and Nizakat (1993). The presence of anti nutritional factors such as trypsin inhibitors and chemotryosin inhibitors in legumes covers the digestibility of legume protein (Enwonwu, 1983). Other anti-nutritional factors such as tannins, phytates, anthocyannins and hemaglutinins impart bitter or unacceptable taste to the legumes, prevent protein digestibility and decrease the absorption of divalent metal ions such as $\mathrm{F}^{2+}, \mathrm{Zn}^{2+}$ in the intestine. This is achieved by complexing with these metals and then making them unavailable for absorption. Many approaches have been adopted to address problems associated with legumes in food/feed.

The effect of cooking, roasting and authoclaving on mineral composition has been reported for some legumes. Also, the effect of soaking, sprouting and roasting on pigeon pea (Cajanus cajan) and Bambara groundnut (Vigna subterna) have been reported (Elegbede, (1998). And finally, the effect of authclaving, soaking and germination have also been reported too for lima bean (Phaseolus lunatus $)^{7}$. The legumes refer to the edible seeds of leguminous plants belonging to leguminosae family(Elegbede, (1998). The family consists approximately 650 genera and 18,000 species; it is divided into three sub-families, namely caesalpinaceae, mimosaceae and papilonaceae (El-Moniem, Honke, and Bedarska, (2000). All legumes bears pods which may be round, flat or winged, long or short, thick or thin, straight or cooled, woody or flushy. The pods usually split longitudinally at one or both edges to expose and release the seeds that it contains. The number of seeds that is contained in a pod ranges from one to several dozens. Commonly consumed legume contains $17-25 \%$ protein. The potential for protein production in most important area is greater for legumes than in cereals. Legumes meet their rot needs for nitrogen without requiring fertilizers by using the nitrogen fixing bacteria - their root nodules contain a group of soil bacteria called Rhisobium which are able to symbiotically trap nitrogen from the atmosphere and convert it to amino acids and consequently to proteins through a series of biochemical reactions.

The valve of legumes in improving soul fertility has been known since ancient times. It is however only towards the end of the $19^{\text {th }}$ century that it was found out that legumes add nitrogen to the soil. Many species of legumes have nodules on their roots containing bacteria which have the ability of fixing atmospheric nitrogen that are available to the host plant. The soul nitrogen is also increased by bacteria are supplied with carbohydrates by the host. This property makes legumes very important in agriculture; they provide protein rich food for man 
and livestock. They are used in mixture with grasses and pastures as well as cover crops and green pastures. In this study, a comparative assessment was made on the effect of sprouting on in vitro digestibility of some seeds used as food.

The legumes reefer to the edible seeds of leguminous plants belonging to leguminosae family (El-Moniem, Honke, and Bedarska, (2000). The family consist approximately 650 general and 18,000 species. It is divided into three sub-families, namely casalpinaceae, mimosaceae and papilonaceae ${ }^{9}$. All legumes bear pod which may be round, flat and winged, long or short, thick or thin, straight or coiled, woody or fleshy. The pods usually split longitudinal at on or both edges to expose and release the seeds that it contains. The number of seeds that it contained in a pod ranges from on $\mathrm{e}$ to several dozens. Commonly consumed legume contains $17-28 \%$ protein. The potential for protein production in most important area is greater for legumes than in cereals (Heatman and Kestler (1989). Legumes meet their needs for nitrogen without requiring fertilizer by using the nitrogen fixing bacteria. Their root nodules contain a group of soil bacteria called rhizobium which are able to symbiotically trap nitrogen from the atmosphere and convert it to amino acid and consequently to protein through a series of biochemical reactions (Lawrence, (1987). The value of legumes in improving soil fertility has been known since ancient times. It is however only towards the end of the $19^{\text {th }}$ century that it was found, that legumes add nitrogen to the soil. Many species of legumes have nodules no their roots containing bacteria which have the ability of fixing atmospheric nitrogen that are available to the host plant. The soil nitrogen is also increased by bacteria supplied with carbohydrates by the host. This property makes legumes very important in agriculture with grasses and pastures as well as crops and green pastures (Meyer. (1973).

\section{MATERIALS AND METHODS}

Source of Samples: Samples were bought from open market at Ihievbe, Owan East Local Government Area, Edo State, Nigeria. Samples were identified in Botany Department, Ambrose Alli University, Ekpoma.

1. Cowpea (Vigna unguiculata)
2. Sayabeans (Glycine max)

3. Pigeon pea (cajanus cajan)

4. Bambara beans (Vigna substerrabean)

Treatment of samples: Representative portions were put into a beaker containing $500 \mathrm{ml}$ of water. Samples that floated were discarded as not viable. Viable samples were soaked for 30 minutes to imbibe water. They were subsequently removed and rinsed in $1 \%$ sodium benoate solution to inhibit fungi growth during germination.

Germination: Sprouting was done in Petri dishes containing soaked tissue paper for 3 days. The samples were kept moist daily by wetting with water. They were confined in locked-up cupboard.

Processing of samples: On each day after sprouting, samples were collected and dried in airdrought oven (at $55^{\circ} \mathrm{C}$ to constant weight). The dried samples were subsequently pulverized and sieved through a $1 \mathrm{~mm}$ diameter sieve before used for analysis.

Analysis: Samples for analysis consist of ungerminated raw sample; ungerminated cooked sample, uncooked germinated samples respectively. $50 \mathrm{ml}$ of aqueous suspension of sample $(27 \mathrm{~g} / 100 \mathrm{ml})$ was used. The $\mathrm{pH}$ of the solution was adjusted to 8 with $0.1 \mathrm{~m} \mathrm{NaOH}$. Subsequently, $10 \mathrm{ml}$ of multi enzyme mixture containing 1-6mg trysin, 3.1mg chemotrypsin and 1-3 peptidase per ml were added. The slurry was then incubated for 15 minutes in water bath (at $37^{\circ} \mathrm{C}$ ). The $\mathrm{pH}$ of the solution was then read and the in vitro digestibility calculated from the equation (Sathe, Destipaude, and Salunke, (1987).

$$
\mathrm{Y}+210.464-18.103 \mathrm{X}
$$

Where: $\mathrm{Y}=$ digestibility; $\mathrm{X}=\mathrm{pH}$ value

Triplicate samples were read subjected to single analysis of variance test. Results were expressed as mean \pm standard error of mean.

\section{RESULTS AND DISCUSSION}

Table 1 shows the result of analysis carried out to assess the effect of germination and cooking on in vitro digestibility of some varieties of commonly consumed legumes. 
Table 1: Result of the effect of germination and cooking on in vitro digestibility of some varieties of commonly consumed legumes

\begin{tabular}{|c|c|c|c|c|}
\hline Treatment & $\begin{array}{l}\text { Pigeon pea } \\
\text { cajan) }\end{array}$ (Cajanus & $\begin{array}{ll}\text { Soyabeans } & \text { (Glyine } \\
\text { max) }\end{array}$ & $\begin{array}{l}\text { Bambara beans } \\
\text { (Vigna subterranean) }\end{array}$ & $\begin{array}{l}\text { Cowpea (Vigna } \\
\text { Unguiculata) }\end{array}$ \\
\hline A & $94.12 \pm 0.56$ & $94.48 \pm 0.37$ & $101.49 \pm 0.88$ & $94.55 \pm 0.37$ \\
\hline B & $94.55+0.43$ & $97.08+0.67$ & $99.67+0.40$ & $103.6 \overline{6}+0.49$ \\
\hline $\mathrm{C}$ & $99.37 \pm 0.23$ & $89.36 \pm 0.30$ & $94.61 \pm 0.43$ & $97.62 \pm 0.46$ \\
\hline $\mathrm{D}$ & $99.49+0.37$ & $95.81+0.37$ & $92.79+0.40$ & $98.35+0.37$ \\
\hline
\end{tabular}

Results are given as Mean 94. \pm SEM of triplicate determinations; $A=$ Ungerminated uncooked; $B=$ Ungerminated cooked ; $C=$ Germinated uncooked; $D=$ Germinated cooked $C=$ Cowpea (Vigna unguiculata)

All sample recorded mean statistical difference for raw, cooked and germinated sample $(\mathrm{P}<0.05)$. This implies that cooking and germination had positive effect on digestibility of the samples as analyzed. The ungerminated raw sample of Bambara beans (Vign substerranean) recorded the highest digestibility. However, cooked ungerminated sample recorded improved digestibility except Bambara beans that recorded decreased digestibility. The digestibility recorded by cowpea (vigna unguiculata) on cooking was highest, 1103.66 \pm 660.08 , hence, cooking is a favourable means of improving digestibility of most legumes seeds for food. On germination, all samples recorded improved digestibility than raw or cooked samples except for Soya bean (Gluycine max). Cooking of germinated samples recorded comparable digestibility for cowpea, lower digestibility for Bambara beans and improved digestibility of germinated raw soya beans samples compare with the observation that sprouting of rapeased exhibited a significant decrease $(82.8 \%)$ in digestibility (Oshodi and Hall, (1993)' (Bedsheh,. Sattar, and Nizakat, 1993). Improved digestion as recorded for others support the assertion that the use of germinated heattreated soya beans, lupin and black bean on their own and as food ingredient is nutritionally advantageous due to the low content on non digestible oligosaccharides and high protein utilization (Badsheh, and Nizkat, (1993) Effect of irradiation and other processing methods on in vitro digestinbility of rapseed protein. J. Sci. Food Agric.61:273 - 275 The improved digestibility recorded after cooking may be ascribed to heat in activation of toxic factors as notices in the study on the influence of heat processing of Africa Yam bean seed (sphenostylis stenocarpa) flour on the growth and organ weight of rats.

Conclusion: The study indicates that sprouting is not a favourable means of improving digestibility of local varieties of Bambara (Vigna subterranean) and soya bean (Glycine max). However, it serves to improve digestibility of pigeon pea (Cajanus cajan) and cowpea (vigna unguiculata). This implies that their content of non digestible oligosaccharides was lowered. And finally, with pigeon pea recording in vitro digestibility of $99.40 \%$ after sprouting and

${ }^{* 1}$ Egwaikhide, P A; ${ }^{1}$ EguavoeN, I.O; ${ }^{2}$ Akporhonor, E E cooking. It will record growth performance index better than cowpea, soya bean and Bambara beans. Hence, it will serve better for weaning animals than the other studied legume seeds.

\section{REFERENCES}

Aletor, V.A. and Aladetimi, O.O. (1989). Compositional evaluation of some Cowpea varieties and under utilized edible legumes in Nigeria. Die 33:pp. $999-1007$.

Auret, M. and Behar Syndrome, M. (1953). Polycorencies de'I Entrant (Kwashiokor) et sa prevention en Amerique FAO No.13

Bresssani. R. (1975). Legumes in human diet and how they might be imght be improved. In : polyphenols in cereals and humes. Milner (ed.) IDRE Ottawa, Canada.

Badsheh. A . A.., and Nizakat, B. (1993). Effect of irradiation and other processing methods on in vitro digestibility of rapseed protein. J. Sci. Food Agric. 61: $273-275$.

Enwonu, C.O. (1983). A review on the nutrient requirements and nutritional status of Nigerians. In: Nurtition and food policy in Nigeria. T. Atinmon and L. Akinyele (eds.) NIPASS Pub. Jos.

Elegbede, J. A. (1998). Legumes. In: Nutritional quality of plant foods. Osagie A. U. and Eka O.U. (eds.). Post Harvest Research Unit, Benin City. Pp 53-83.

Elegbede, J.A. (1998). Legumes Nutritional quality of plant foods. Osagie A.U. and Eka O.U. (eds) Post Harvest Research Unit, Benin City. Pp 5366

El-Moniem, G.M. Honke, J and Bedarska, A. (2000)). Effect of frying various legumes under optimum conditions of amino acids in vitro digestibility, phytate and oligocassharide J. Sci. Agric. 80: 57-62 
Heatman and Ketler (1989)). Principles of propagation by seeds. Plant propagation P. 122 . Prentice Hall of India.

Igbedioh, S.O. Olugbemi, K. and Akpapunam, M. (1984). Effects of processing methods on phytic acid level and some constituents in Bambara groundnut (vign substerranean) and pigean pea (cajanus). Food Chem. 50: 147-151.

(Lawrence, K.O. 1987). Methods of propagation. Tropical Tree Crops. Pp. 27-28.

Meyer A.B.F. (1973). Germination and dormancy. In: Introduction to plant physiology. Litton Educational Publishing Inc. P. 533

(Ologbo A.D. Fetuga, B.L. and Tiwe, O.O. (1984). The cyanogenic content of raw and processed lima bean varieties. Food chem. 13:117-128

(Oshodin, A.A. and Hall , G.M. 1993)). In vitro multienzyme digestibility of protein of some plant source flour blended with bovine plasma protein concentrate J. Sci. Agric. 63:323-327.

Onyeike, E.N., Ayakulu, E.O. and Uzogara, G.S. (1995)). Influence of heat processing of Africa yam bean seed (Sphenostylis Stenocarpa) flour on the growth and organ weight of rats. Plant Food for Human Nutrition 48:85-93.

(silamo, V. Bansul, H.C. and Bozzini, A. (1982)). Improvement of nutritional quality of plant food crops. FAO plant protection, FAO Rome. P.34

Sathe, S.K., Destipaude, S.S. and Salunkhe, D.K. (1987)). Functional properties of lipid seed oil (Lupinus metabilis) proteins and protein concentration. Journal of Food Science. 47: 491497.

(Taugo, L.C., Donangelo, C.M., Taugo, N.M.F. and Knudsen-Bach, K.E. (2000)). Effect of heat treatment on nutritional quality of germinated legume seed J. Agric. Food Chem. 48: 20822086. 